\title{
МЕТОДОЛОГІЯ ПРАВА
}

УДК 340.12:005.001

doi: https://doi.org/10.33270/01191702.32

Кельман М. С. - доктор юридичних наук, професор, професор кафедри теорії та фрілософії права ННІПП Національного університету «Львівська політехніка», м. Львів ORCID: https://orcid.org/0000-0002-4393-4626;

Кельман Л. М. - кандидат юридичних наук, доцент, доцент кафедри цивільного права та процесу Львівського державного університету внутрішніх справ, м. Львів ORCID: https://orcid.org/0000-0001-6884-0389;

Романська I. В. - аспірант Львівського державного університету внутрішніх справ, м. Львів ORCID: https://orcid.org/0000-0001-6970-184X

\section{Осмислення методології пізнання наукових теорій у правознавстві}

Мета і завдання статті полягають у тому, щоб представити дослідницьку програму правознавства. 3 науково-історичної позиції це консервативне прагнення, оскільки спрямоване не на заміщення наявних виявів уявно оригінальними, а на консолідацію правознавства, а також революційне, адже спрямоване на новий шлях правознавства: реалізувати дослідницьку програму означає безперервне (постійне) дослідження, отже, відмову від певних коливань модними течіями між забутим і нововідкритим, означає розуміти правознавство підкреслено як науку, а отже, поворот від політизованої «наради, де приймаються рішення». Методологічну основу дослідження становить низка концептуальних підходів, загальнонаукових $і$ спеціально-наукових методів. Розглянуто актуальні питання методології пізнання наукових теорій. Досліджено наукові теорії сучасного правознавства, їх структура. Обгрунтовано розвиток правознавчих теорій у загальній структурі наукових теорій. Зазначено, що на правознавство маргінальний вплив мало фрормулювання питання наукової теорії, у кожному разі до сьогодні. Якщо значення науково-теоретичних досліджень дедалі більше є важливим для правознавства, то не можна сперечатися, що наукова теорія правознавства досі не перебуває в полі зору в конкретній фоормі. Відображаючи їі сучасний стан, слід констатувати поле напруги, з одного боку якого стоїть пізнавальне намагання довкола науково-теоретичної основи науки, а з іншого - так звана правова догматика, яку обслуговує (якщо взагалі обслуговує) наявна тимчасова теорія про ї̈ основу. Акцентовано увагу на організації правознавства як науки. Розглянуто проблему вартісної свободи науки, яка нас різним чином цікавитиме та стосуватиметься. Обгрунтовано, що кожна наука користується інструментарієм логіки. Водночас слід розрізняти висловлювання про оцінку та здійснення оцінки: висловлювання про оцінку $є$ висловлюванням про те, що певні оцінки взаємозалежать у системі вартості або про те, чи хтось осягнув для себе певні оцінки. Натомість проведення оцінювання означає брати на себе оцінювання, самому оцінювати. Наукова новизна одержаних результатів полягає в тому, що досліджено та представлено дослідницьку програму правознавства через розуміння ії як науки. Постулат "вартісна свобода науки» не слід розуміти як те, що висловлювання про оцінювання не належать до науки, що було б ненауковим робити оцінювання предметом пізнання. Ідеться про те, що проведення оцінювання (безпосередня оцінка) не належить до наукової діяльності. Загальна наукова теорія намагається відповісти на важливий аспект запитання «що є наука?». Питання організації науки є питанням про передумови, з яких необхідно виходити, щоб можна було займатися спеціальною науковою діяльністю. Очікування (надія) наукової теорії полягає $в$ тому, що з неї можна вибирати, за якими критеріями можна перевіряти наукові норми на їхню правдивість. Імовірно, хтось навіть очікуе, що наукова теорія може вказати йому шлях («метод»), яким потрібно лише механічно слідувати, щоб досягнути мети наукового пізнання. Які очікування мають також зокрема $і$ яку відповідь також бажає підготувати наукова теорія: для науково-теоретичних норм, як $і$ для будь-яких інших норм, необхідні критерії перевірки. Наукова теорія з'являється як наука, що, зі свого боку, потребує наукової теорії, для якої надалі ніщо інше не може діяти. Висновки. Виникла шкала (послідовність, градація), метамета - мета наукової теорії, яка є безконечною, тому не може бути до кінця простежена, а наші критерії перевірки, мабуть, не підлягають обгрунтуванню. Ті науково-теоретичні теорії, які нібито діють лише для природничих наук або інших галузей, можна було б назвати, на противагу Загальній науковій теорії, «Особливою науковою теорією».

Ключові слова: теорія; наука; методологія; метод; система; структура; організація; істина; логіка; програма; правознавство.

\section{Вступ}

Критичний аналіз літератури розвитку наукових теорій дає підстави визнати, що досі не вдалося поєднати розпочаті проекти, які походять із кінця 70-х - початку 80-х років, у безперервне дослідження. Також не можна стверджувати, що розвиток наукових теорій зупинився сьогодні, проте не можна не визнавати певного сповільнення розвитку й того, що наукові теорії фактично було відірвано від своєї юридичної основи й орієнтовано на пропаганду панівної ідеології та політики керівної партії. До 
проблем наукових теорій зверталися такі вчені: Аристотель, Х. Альберт, В. Астафєв, Ф. Бекон, В. Вернадський, Гіппократ, Ф. Гегель, Ч. Дарвін, Р. Декарт, Д. Заболотний, Г. Кельзен, Б. Спіноза, А. Тарський, А. Шопенгауер та ін.

Наукова теорія не може замінити науку, вона не $\epsilon$ автоматом, який у разі правильного використання постачає незаперечні наукові пізнання, - вона $€$ насамперед необхідною передумовою наукової діяльності. Кожен науковець має наукову теорію, яка має вагомий вплив на його дії, а отже, на його наукові результати. Дослідження структури правознавчих теорій відбувається шляхом розгляду питань диференціювання між різними правознавчими теоріями. Водночас необхідно розрізняти й відображати теорії різних рівнів, з огляду на їхній предмет. Як правознавчі теорії різних рівнів залежать одна від одної в їхніх передумовах. Цей опис низки правознавчих теорій не висвітлює можливості обміну правознавчих дослідницьких програм. Зважаючи на це, правознавчі теорії зображують не як змінну величину з невизначеним змістом, як «чорну скриньку», в кожному випадку також зазначено основні напрями того, що вони містять. Унаслідок цього слід надати найважливіші положення правознавства від метатеорії загальної наукової теорії до теорії певної галузі права. Метод, який лежить в основі цієї дослідницької програми, стосується двох величин: однією $€$ теорії різних рівнів від теорії нульового рівня до особливого правового вчення - цю величину має бути тут повністю представлено, оскільки, лише спираючись на неї, можемо дослідити другу величину: деталізацію виявів відповідного рівня теорії. 3 останньої величини, звичайно, може бути представлено лише «верхівку» - в ії наповненні полягає виконання дослідницької програми.

Питання організації науки є питанням про передумови, з яких необхідно виходити, щоб можна було займатися спеціальною науковою діяльністю. Очікування (надія) наукової теорії полягає в тому, що з неї можна вибирати, за якими критеріями перевіряти наукові норми на їхню правдивість.

Згідно з теорією консенсусу (згоди) правди (істини), висловлювання $є$ лише тоді істинним, якщо існує консенсус щодо висловлювання. Точне фрормулювання цієї теорії правди зазначено в різних версіях.

Завдяки цьому дослідженню здійснено спробу віднайти ефективні дослідницькі шляхи в теорії права та правознавстві, зокрема. Водночас ми сподіваємося, що окреслена ситуація теорії права відкриває шанс для нового осмислення. Це нове осмислення не може ґрунтуватися на сподіваннях мати ідею для специфічної, оригінальної концепції правознавства. Насправді йдеться про те, щоб знайти межі, де могли б бути пов'язані численні нововведення й окремі аналітичні досягнення. Знайти межі, котрі пропонують міцний фундамент для подальших науково-правознавчих дослідницьких праць.

\section{Мета і завдання дослідження}

Мета і завдання дослідження полягає в тому, щоб представити дослідницьку програму правознавства. 3 науково-історичної точки зору це як консервативне, так і революційне прагнення. Наше прагнення $€$ консервативним, оскільки воно спрямоване не на заміщення наявних виявів уявно оригінальними, а на консолідацію правознавства. На противагу цьому воно виявляється як революційне, оскільки спрямоване на новий шлях правознавства: реалізувати дослідницьку програму означає безперервне (постійне) дослідження, а отже, відмову від певних коливань модними течіями між забутим та нововідкритим, означає розуміти правознавство підкреслено як науку, а отже, поворот від політизованої «наради, де приймаються рішення».

\section{Виклад основного матеріалу}

\section{I. Проблема правознавчих meорій.}

Тільки-но наукове прагнення перевищує ступінь примітивного знайомства з предметом, що розглядають, як постає питання щодо критеріїв перевірки наукового пізнання. Наука стає предметом дослідження - предметом наукової теорії. Наукова теорія не може замінити науку, вона не $\epsilon$ автоматом, який у разі правильного використання постачає незаперечні наукові пізнання, - вона $є$ насамперед необхідною передумовою наукової діяльності. Зокрема, Поппер зазначає, що «всі люди мають філософію, знають вони це чи ні» (Popper, 2004). Можна також наголошувати, що кожен науковець має наукову теорію, яка має вагомий вплив на його дії, а отже, на його наукові результати.

Розвиток формальної логіки, що було розпочато в останній третині минулого століття, не лише призвів до методичної появи у «формальних науках» логіки та математики, а й спонукав до осмислення всіх наукових сорер i таким чином сприяв становленню наукової теорії як окремої галузі науки. Предметною сфрерою наукової теорії $€$ саме «наука», хоча різноманітні проблеми зараховують до «логіки дослідження», оскільки вони стосуються лише основ науки. 3 певного часу в центрі уваги наукової теорії перебувають здебільшого питання утворення теорій і структура теорій. Питання щодо структури наукової теорії спрямоване в ядро наукової теорії та може, з огляду на це, бути початком науково-теоретичних досліджень (Popper, 2004, p. 67). 
На правознавство маргінальний вплив мало визначення питання наукової теорії, у кожному разі до сьогодні. Якщо воно так $є$, що значення науковотеоретичних досліджень дедалі більше є важливим для правознавства, то не можна сперечатися, що наукова теорія правознавства досі не перебуває в полі зору в конкретній формі. Якщо хочуть відобразити її сучасний стан, то слід констатувати поле напруги, з одного боку якого стоїть пізнавальне намагання довкола науковотеоретичної основи науки, а з іншого - так звана правова догматика, яку обслуговує (якщо взагалі обслуговує) наявна тимчасова теорія про її основу.

Уже ця ситуація була б приводом для наявного дослідження. Необхідно визначити, що це не лише в абстрактному сенсі $€$ «дефріцитом теорії», а й таким чином, що вже виникли проблеми, які потребують дослідження структури теорії в правознавстві. Тож, не лише збільшилися вимоги до правознавства завдяки комплексній системі регулювання, а й стала більш змістовною представлена правознавча концепція для виконання цих завдань. Це ствердження діє не тільки для окремої правознавчої концепції. Більшою мірою збільшується кількість концепцій, які знаходяться у дискусії.

Ми стоїмо перед ситуацією, коли дедалі більша потреба в дослідженні протистоїть дослідницьким розробкам (кількість яких збільшується), що залишаються в розробленні через їхню недостатню координацію. Виникає небезпека, що підвищена складність наукових досліджень зменшує ефективність правознавства та призводить до того, що правова практика в майбутньому відвертається від правознавства та відхиляється від тимчасової теорії. За таких умов ми мали б результат, що в однаковому співвідношенні, у якому правознавство підсилює свої намагання, узгоджується раціональність правової практики, замість того, щоб, як сподіваються дослідники, зростати.

Цю проблему «зовнішнього впливу» правознавства супроводжує «внутрішня» проблема: вона позначається питанням наукового характеру правознавства. Про науковість чи не науковість правознавства давно тривають суперечки. Легко розглянути, чому ця дискусія проходить повз власну точку: про науковість правознавства можна говорити лише тоді, коли щось таке як «правознавство» взагалі існує. 3 такої позиції нескладно досліджувати ту чи іншу концепцію правознавства. Фактично проблема полягає в тому, що немає єдиної концепції правознавства. Такий плюралізм сприяє взаємному непорозумінню та призводить до того, що виникає окреслена ситуація: правник кладе в основу своєї праці власне відповідне розуміння правознавства у такому разі можна не дивуватися щодо труднощів розуміння, які 3 цього випливають.
Фаховий юрист потребував би обирати концепції правознавства, які $є$ для нього «відповідними» або «розумними», проте водночас не доходив би подальших висновків. Як наслідок, спостерігаємо домінування спонтанно запланованих науковотеоретичних уявлень у правознавстві, що часто $\epsilon$ непродуманими, оскільки здебільшого неодноразово зроблено явно.

Ці визначення не вважають (що найменше не першочергово) критикою способу дії окремого фахового юриста. Його завданням не може бути створення самотужки наукової теорії правознавства перед тим, як він розпочне працювати. Він діє раціонально (й ефективно), якщо приймає звичну йому концепцію правознавства за основоположну, яку за потреби спонтанно доповнює. Проте має бути з'ясовано, що недостатній науково-теоретичний фундамент правознавства $\epsilon$ важливою підставою для втрати ефективності, що сумнівність (невизначеність) принципів правового аналізу має нести не лише правознавець, а й кожен, хто бере участь у правовому житті (цю невизначеність у багатьох випадках перекриває видима безпека).

Таке формулювання проблеми визнають не лише сьогодні. Із заголовком «теорія права» певний час намагаються розвинути розповсюджені й основоположні концепції правового аналізу (правова логіка та правова інформатика), а 3 іншого боку - встановити наукову теорію правознавства.

Критичний оглядач цього розвитку повинен визнати, що досі не вдалося поєднати розпочаті проекти, які походять із кінця 70-х - початку 80-х років, у безперервне дослідження. Також не можна стверджувати, що розвиток теорії права зупинився сьогодні, проте не можна не визнавати певного сповільнення розвитку.

Серед причин слід назвати такі: спочатку $€$ ейфорійне недооцінювання складності завдань, які необхідно виконати (це більшою мірою для правової інформатики), в майбутньому передовсім накопичення лише фрагментарних досліджень. Зокрема, питання «чим корисний теоретико-правовий аналіз проникнення (наповнення) правового матеріалу?» часто занадто поверхнево опрацьовано - 3 наслідком недооцінювання детальних проблем (унаслідок чого фахові юристи не виявляють бажаного зацікавлення теорією права). Проте ця ситуація не $є$ тривожною. Вона видається вираженням регулярності, яку знаходять під час кожної спроби розв'язання доволі складних проблем. Діяльність можуть приймати лише на підставі певної ейфорії, яку перед обличчям реальних труднощів невдовзі замінить депресивний настрій. У приєднанні до цієї фрази розчарування настає рішення про припинення чи подальше ведення діяльності. 
Унаслідок тиску проблеми, що обтяжує правознавство, це дослідження намагається посприяти тому, щоб віднайти ефективні дослідницькі шляхи в теорії права та правознавстві, зокрема. Водночас сподіваємося, що окреслена ситуація теорії права відкриває шанс для нового осмислення. Це нове осмислення не може ґрунтуватися на сподіваннях колись мати ідею для специфічної, оригінальної концепції правознавства. Насправді йдеться про те, щоб знайти межі, де могли б бути пов'язані численні нововведення й окремі аналітичні досягнення. Знайти межі, які пропонують міцний фундамент для подальших науково-правознавчих дослідницьких праць.

Головна мета статті - представити дослідницьку програму правознавства. 3 науковоісторичної точки зору це як консервативне, так i революційне прагнення. Наше прагнення $€$ консервативним, оскільки спрямоване не на заміщення виявів уявно оригінальними, а на консолідацію правознавства. На противагу цьому воно виявляється як революційне, оскільки спрямоване на новий шлях правознавства: реалізувати дослідницьку програму означає безперервне (постійне) дослідження, а отже, відмову від певних коливань модними течіями між забутим i нововідкритим, означає розуміти правознавство підкреслено як науку, а отже, поворот від політизованої «наради, де приймаються рішення».

Якщо ми розуміємо правознавство як науку, тоді ми не будемо насамперед обговорювати критично щодо їхньої науковості наявні концепції правознавства, а зробимо основним питання: яким чином правознавство $є$ можливим як наука? Результат цієї конструктивної спроби може бути, вочевидь, основою критики, проте критика не $є$ в центрі уваги.

Дослідження структури правознавчих теорій відбувається шляхом розгляду таких питань:

1) про диференціювання між різними правознавчими теоріями. Водночас необхідно розрізняти теорії різних рівнів та відображати їх, 3 огляду на їхній предмет;

2) про зв'язок цих різних теорій - питання про те, як правознавчі теорії різних рівнів залежать одна від одної в їхніх передумовах. У низці правознавчих теорій не зазначено про можливості обміну правознавчих дослідницьких програм. 3 огляду на це, правознавчі теорії відображають не як змінну величину з невизначеним змістом, як «чорну скриньку», в кожному випадку також окреслено основні напрями того, що вони містять. Унаслідок цього слід представити найважливіші положення правознавства від метатеорії загальної наукової теорії до теорії певної галузі права. Метод, який лежить в основі цієї дослідницької програми, стосується двох величин: теорії різних рівнів від теорії нульового рівня до особливого правового вчення (цю величину має бути тут повністю представлено, оскільки, лише спираючись на неї, можемо дослідити другу величину); деталізація виявів відповідного рівня теорії (може бути представлено лише «верхівку» - в ії наповненні полягає виконання дослідницької програми).

Це - грубе конструювання, досягнуте в першій частині дослідження. 3 огляду на мету статті, достатньо покласти основне завдання на позитивне концептування - критичний розгляд лише найважливіших окремих концепцій не тільки підривав би обсяг дослідження (і залишив би його від початку безнадійним ризиком), а й завдавав би шкоди насамперед прозорості перебігу думок. Автор спробував відкинути оригінальність послідовно за рецепцію майже наявних виявів, що обіцяли успіх. Водночас відкрився критичний розгляд інших концепцій, необхідних для конструювання (окреслення).

Правничо-теоретична відправна точка, яку тут насамперед підтримуємо, $\epsilon$ обґрунтоване Г. Кельзеном чисте (абсолютне) правове вчення. Читач, який знає твори Г. Кельзена, скоро помітить, що ця праця навіть там, де вона не безпосередньо згадано принципи чистого правового вчення, несе основні думки та принципи чистого правового вчення. Причину цього можна шукати в тому, що, водночас, чистим правовим ученням існує солідний фундамент засобів наукового правового пізнання. Слово «фундамент» визначає, що багато з того, що в дотеперішньому формулюванні (викладі) чистого правового вчення лише було окреслено, необхідно відзначити й доповнити. Сфера використання чистого правового вчення таким чином розширюється. Також слід висвітлити дещо незрозуміле та беззмістовне в залученні "сучасних" аналітичних методів або лише принципів найбільш чистого правового вчення. Якби таку мету хотіли назвати, то можна було б сказати, що ії спрямовано на «консолідоване чисте правове вчення» (Kelzen, 2015).

Можливість обміну представленої дослідницької програми (а таким чином також ефрективність чистого правового вчення) могло б бути зазначено у розвідках на підставі певної галузі права. Сюди можна залучити кримінальне право, зокрема ту частину кримінального права, яка зазвичай називається «Загальна частина». Для цього, крім причин, що стосуються автора (особисті інтереси та знання), є також багато об'єктивних причин: «Загальна частина» кримінального права $\epsilon$ галуззю права з порівняно незначною складністю. Також це галузь права із відносно високо розвинутою правовою догматикою, тобто тут терміново постає проблема науковості правознавства. I насамкінець, мова про галузь, яка $€$ цікавою також для юристів інших галузей права. 
Вирішальним для вибору предмета був такий феномен: усередині вчення про «Загальну частину» кримінального права постає неабияка невизначеність статусу її норм: це норми про наявні регулювання в певному кримінальному законі чи йдеться про норми, які діють для всіх кримінальних законів?

Цієї проблеми досі не було визнано, оскільки в освітньому процесі підґрунтям завжди був певний позитивний кримінальний закон. Попри це, можна продемонструвати, що в низці пунктів такого викладу в основі лежить уявлення, «власне кажучи», ці виконання $€$ загальноприйнятими, а отже, не пов'язаними з певним кримінальним законом.

Поставлене завдання, 3 огляду на цю позицію, - відокремити такі загальноприйняті норми від тих, які діють, лише зважаючи на певний кримінальний закон. У цьому сенсі ми розрізняємо Загальне кримінально-правове вчення (як галузь Загального правового вчення) й Особливе кримінально-правове вчення (як галузь Особливого правового вчення). У другій частині статті ми хочемо продемонструвати, що і як таке Загальне кримінально-правове вчення $\epsilon$ можливим, чим тоді, наприклад, демонструємо, що і як таке Загальне правове вчення в загальному $€$ можливим. Досягнення у першій частині роботи є дуже продуктивними для аналізу певної галузі права.

Отже, спочатку досліджено, як правознавство як наука $€$ можливим, яке місце може знайти це правознавство в системі наук і яку структуру загалом посідають правознавчі теорії. Тоді зображено структуру правознавчих теорій на прикладі Загального кримінального вчення. Розроблення мети цієї спроби - наочно продемонструвати загальні наслідки здобутих нових понять правознавства для правознавчої праці. Представник традиційної правової догматики робить закид, що правознавство, якому байдуже до того, щоб попереджувати насамперед рішення осіб, котрі застосовують право, або законодавців, проте в якому спершу йдеться про те, щоб шукати проблеми та ставити правильні запитання, $€$ нецікавим і суспільно не важливим. Такі «закиди» неправомірні (необґрунтовані), оскільки ґрунтуються на очевидному недооцінюванні складності такого правознавства. Здебільшого ми віримо, що по-новому, зрозумілому «лише» науковому правознавству підходить суспільне значення, яке ніколи не може мати догматизовану правову політику та законодавство 3 підручника. Нас цікавить також реабілітація правознавства, стосовно якого виявляється неповага представників інших галузей науки.

У другому розділі ми будемо досліджувати місце правознавчих теорій у загальній побудові наукових теорій. Для цього спочатку необхідний дослідницький погляд на організацію (становлення) науки.

\section{II. Організація науки}

Тут ідеться про те, щоб показати, як правознавство може організовуватись як наука, а отже, про те, як правознавство є можливим як наука. Водночас нас не цікавить питання, якою мірою те, чому зазвичай приписують назву «правознавство», $є$ наукою або ні. Такий вирок який сенс це могло б мати - може бути можливим, лише якщо мати перед собою організоване правознавство як науку.

Організація (становлення) правознавства передбачає аналіз організації науки загалом.

1. Теорія нульового рівня: основні передумови науки

Питання, яке необхідно насамперед дослідити: як організовується наука?

Слід визначити, чому ми не ставимо питання «що таке наука?», хотілося б, щоб виникало враження, ніби цим шляхом найшвидше досягають мети. Уже зміст цього питання не зовсім зрозумілий, воно принаймні може мати на увазі різні аспекти (для чого служить наука; які вимоги мусить виконувати норма, щоб мати змогу діяти як наукова; чому займаються наукою; якими $€$ передумови науки тощо). Ми прагнемо розрізняти ці аспекти й, оскільки вони тут мають значення, один за одним розглянути. Лише так можна сподіватися на обґрунтовану відповідь (яка також мусить бути відповіддю на питання «звідки можна знати, що є наука?»).

Ми хочемо спочатку залишити відкритим питання, що $€$ наука. Водночас не можемо та не хочемо відфільтровувати повсякденне розуміння слова, яке має кожен, проте не будемо поєднувати подальші висновки із цим повсякденним мовним уживанням - його вживають (застосовують) лише для зручності (тут ми приймаємо, що надалі не мусимо пояснювати, що й наскільки «наука» та «халява» $€$ дуже різними).

Питання організації науки $€$ питанням про передумови, на які слід зважати, щоб займатися спеціальною науковою діяльністю. Очікування (надія) наукової теорії полягає в тому, що з неї можна вибирати, за якими критеріями перевіряти наукові норми на їхню правдивість. Можливо, хтось очікує, що наукова теорія вкаже йому шлях («метод»), яким необхідно лише механічно слідувати, щоб досягнути мети наукового пізнання. Які очікування мають, зокрема, і яку відповідь бажає підготувати наукова теорія: для науково-теоретичних норм так само, як і для будь-яких інших, потрібні критерії перевірки. Наукова теорія з'являється як наука, що, зі свого боку, потребує наукової теорії, для якої в майбутньому ніщо інше не може діяти. Таким чином виникла шкала (послідовність, градація), мета-мета - мета наукової теорії, яка $€$ 
безконечною і тому не може бути до кінця простежена, а таким чином наші критерії перевірки, мабуть, не підлягають обґрунтуванню.

Цій проблемі фундаменту наукової теорії не приділяють належну увагу. Проте якщо ми розмірковуємо про організацію правознавства, то не можемо залишити цю проблему без уваги, бо це ключова проблема науки.

Проблема «останнього (кінцевого) обгрунтування (мотивації, доказу)»

У цій проблемі йдеться про одяг (обрамлення) загальної проблеми кінцевого обґрунтування. Заслугою Х. Альберта $\epsilon$ те, що він упевнено зазначив: мета кінцевого обґрунтування $\epsilon$ недосяжною, це веде до так званої «трилеми Мюнхгаузена».

На шляху до кінцевого обґрунтування, згідно з позицією Х. Альберта, є три можливості:

а) продовжують запитувати про обґрунтування (мотивацію, доказ) - тоді потрапляють у нескінченний регрес;

б) припиняють процес обґрунтування у певній точці - через самовільне (навмисне) рішення без подальших запитань;

в) обирають логічне коло, в якому врештірешт «обґрунтовують» самі собою передумови.

За допомогою трилеми висвітлено поняття «обґрунтування». Логічним колом $€-$ воно мало б бути дійсно логічним - не більш ніж тавтологія. Отже, згідно з логікою, проти нього немає жодних заперечень, лиш тут не існує «справжнього» обґрунтування. 3 перерваним обґрунтуванням логічне коло має спільне те, що воно складається 3 кінцевої кількості аргументів; різниця $€$ виключно прагматичною: в той час, як користувач логічного кола хоче реалізувати одночасно відкритість і сукупність (закритість) аргументації, досягають припинення процесу обґрунтування напряму через заборону осмислення.

Альтернативою перерваного обґрунтування може бути лише повноцінне (цілісне) обґрунтування. Однак вказівка Х. Альберта на те, що повноцінне обґрунтування $є$ можливим виключно в нескінченному регресі, засвідчить: повноцінне обґрунтування не може бути цілісно представлено.

Нині, вірогідно, під час кінцевого обґрунтування науки $€$ випадки, коли повноцінне обґрунтування все-таки $є$ кінцевим. У повторенні прикладу Мюнхгаузена можна було б поставити питання кожному, хто сумнівається в необхідності обґрунтувань (логіці, раціональності загалом): як можна обґрунтовано говорити проти необхідності обґрунтувань? (як можна логічно аргументувати проти необхідності логіки чи раціонально аргументувати проти раціональності?).

Відповідь мала б бути: звичайно, це неможливо! Питанням стосовно обґрунтування того, щоб вимагати обґрунтування, ми потрапили на місце ланцюга обґрунтування, з якого далі не рухаємося. Кожне подальше повернення назад не було б кроком у ланцюгу обґрунтувань (Albert, 2003).

Хоча ми не можемо на цьому місці далі більше обґрунтовувати, проте, мабуть, можемо продовжувати запитувати. I можемо триматися за відповідь: ми зробили аксіоматичне припущення, ми з цього виходимо, оскільки в науці $€$ необхідним вимагати обґрунтувань та подавати їх, зазначав учений В. Вернадський.
Основні
передумови
(припущення,

гіпотези) науки

Наука ґрунтується на основних передумовах, де постає питання аргументувати. Це не нове досягнення. Зазначає про це також А. Шопенгауер: ланцюг суджень (думок) ґрунтується на нормі трансцендентальної чи методологічної правди, і продовжують запитувати: чому. На це немає відповіді, бо питання не має змісту, а саме: не знаємо, якої основи (доводу) воно вимагає. Оскільки норма основи (доводу) є принципом усього пояснення (пояснити річ означає пояснити певний стан (наявність) або причинний зв'язок (обставини) формування норми основи, який має їй відповідати, таким, яким він $є)$, відповідно до цього, норма основи $\epsilon$ сама, це означає причинний зв'язок, оскільки він виражає певну форму, яку далі не можна пояснити; бо немає принципу, що пояснює принцип усіх пояснень, або як око бачить усе, проте не бачить себе (Shopengauer, 1992, p, 47).

Ми дійшли до теорії нульового рівня. Теорія нульового рівня стоїть по інший бік сфери науки, що стосується ії предмета: норми теорії нульового рівня мають своїм предметом не науку (як наукова теорія), а передумови, що роблять, якщо займаються наукою.

Отже, теорія нульового рівня засвідчує: наука базується на передумовах, які можуть зробити, проте не мусять.

Відповідно до цього, лише якщо роблять основні передумови, займаються наукою. । завжди, якщо не роблять цих основних передумов, не займаються наукою. Лише якщо не займаються наукою, не потрібно робити ці основні передумови (Shopengauer, 1992, p, 47).

Водночас ідеться про причинний зв'язок фундаментального значення, про причинний зв'язок, який буде виявлятися ще в інших подібних за структурою проблемах (наприклад, у проблемі обґрунтування дійсності (важливості) норм). Тому ми підкреслюємо цей причинний зв'язок виразніше: немає «вищого» абсолютного обґрунтування для наукового мислення. Немає абсолютної основи (доводу) того, щоб вимагати обґрунтування. Наука базується у підсумку на передумовах, які наважуються робити. Хто не хотів би робити ці передумови, не потребує їх робити - ми не маємо проти нього жодного 
аргументу. Ми не можемо не лише переконати його, що він має зробити нами зроблені передумови (припущення), ми самі не можемо йому нічого заперечувати. Ми можемо лише визначити, що він займається не наукою. Наведемо приклад: хто варить суп із квасолею, той варить квасолевий суп. Якщо замість квасолі візьме горох, тоді він варитиме гороховий суп. Чи він робить одне, чи інше - це лише справа смаку. Зокрема, було б дурістю наголошувати, що суп із квасолі $\epsilon$ «поганим гороховим супом» - це квасолевий суп. У кожному разі, якщо кухар стверджує, що він варить квасолевий суп, у той час, як використовує горох, то ми можемо визначити, що його твердження $є$ неправильним!

Слід передбачити, що ця теорія про підґрунтя наук буде суперечливою. Основною суперечністю $€$ таке: «Якщо кожна наукова діяльність базується на передумовах (припущеннях), які можна робити на розсуд або не робити - тоді наука у кінцевому підсумку не відрізняється від віри в чаклунство або від довільних ідеологій. Абсурдна думка» (Stopin, 2015).

Було б абсурдно, якби наука не відрізнялася від не науки. Це й не стверджується. Акцентовано виключно на тому, що це залежить від кожного зокрема, чи він хоче думати науково, чи ні, і що ми йому не можемо назвати дійсної причини того, чому він має мислити раціонально. Проте також $є$ дійсним: ніхто не може назвати причини для того, щоб думати не науково. Тут постає взаємний імунітет критики проти не науки.

Проте цікавим $€$ такий причинний зв'язок: доволі рідко відкрито відкидають наукове мислення. Частіше стверджують: наукове мислення існує, де в усякому разі є імітація. Такі твердження можуть відображати як фральшиві. Слід зазначити: за структурою вираження (висловлювання) посилання на «вище знання», «недослідженість» або «історичну правду» було 6 не науковим, воно не відрізняється від, наприклад, висловлювання про заперечення існування диявола було б нехристиянським або про підтримку (захист) приватної власності було б не комуністичним. Тобто, висловлювання про те, що певне висловлювання суперечить певним передумовам.

Зважаючи на роль, яку відіграє посилання на наукове пізнання в багатьох сорерах життя (а саме в тому, від чого залежить життя і смерть немалої кількості людей), часто $€$ дуже вирішальною можливість такого висловлювання.

Вартісна свобода (нейтральність) науки

Розглянемо проблему вартісної свободи науки, яка нас різним чином цікавитиме та стосуватиметься. Водночас слід розрізняти висловлювання про оцінку та здійснення оцінки: висловлювання про оцінку $€$ висловлюванням про те, що певні оцінки взаємозалежать у системі вартості, або також про те, чи хтось осягнув для себе певні оцінки. Натомість проведення оцінювання означає брати на себе оцінювання, самому оцінювати. Постулат «вартісна свобода науки» слід розуміти, що висловлювання про оцінювання не належать до науки, що було б ненауковим робити оцінювання предметом пізнання. Постулатом вартісної свободи науки лише слід розуміти, що проведення оцінювання (безпосередня оцінка) не належить до наукової діяльності.

Згідно з теорією нульового рівня, будь-яка наука передбачає прийняття рішення про наукове мислення, а отже, здійснення оцінки. У такій мірі можна було б оскаржувати, що нейтральна наука $€$ можливою. Абсолютно можливо, що ті, хто стверджує, ніби наука не є вільною від передумов, мають це на увазі. 3 іншого боку, слід осмислити, що під час прийняття рішення про науку йдеться про наукове прийняття рішення. Це ще не означає, що всередині науки також було б незамінним здійснення оцінки. 3 огляду на постулат вартісної свободи (нейтральності) науки, можна 3 наших суджень зрозуміти так: науковець приймає рішення щодо нейтрального мислення - він приймає рішення про те (як науковець, наскільки це стосується наукових норм і їхніх обґрунтувань), щоб самому не здійснювати оцінку. Партійний функціонер чи священик, наприклад, на противагу цьому, приймає рішення щодо вартісного мислення - він приймає рішення про те, щоб самому проводити оцінку (щонайменше ту оцінку, щоб лояльно слідувати своїй партії чи церковним канонам).

\section{2. Загальна наукова теорія}

Наукова теорія була від початку науковою теорією природничих наук - насамперед фрізики. Не слід оминати того фракту, що історичну науку та соціологію постійно брали до уваги наукові теоретики, проте ці дві галузі науки було розглянуто лише як проблематичні сфрери, поставало питання, наскільки на основі фрізики розвинуті норми наукової теорії діють також і для них.

Позначення (назва) «наука» для різних галузей науки передбачає, що притаманні їм властивості $€$ спільними - інакше позначення (назва) «наука» для різних сорер було б безглуздим. Надалі ми хочемо ввести назву «Загальна наукова теорія» як позначення галузі наукової теорії, що діє однаково для всіх наук. Загальна наукова теорія $є$, отже, теорією про всі наукові сорери, за допомогою неї відрізняють науку від не науки, визначають критерії науковості.

Отож загальна наукова теорія намагається відповісти на важливий аспект запитання «що $€$ наука?». Ті науково-теоретичні теорії, які нібито діють лише для природничих наук або інших окремих галузей наук, можна було б назвати, на 
противагу Загальній науковій теорії, «Особливою науковою теорією».

Заперечення можливості Загальної наукової теорії могло б десь опиратися на те, що поняття «наука», як його застосовують у повсякденній мові, $є$ багатозначним. По-перше, ним вважають наукові результати - «норми науки»; по-друге, може йтися про наукову діяльність - коли говорять, що хтось займається наукою; по-третє, наукові інституції можна назвати наукою, де «норми науки» застосовують як слово.

Можна було б стверджувати, що спільність (подібність) наук $€$ лише поверхневою, обґрунтованою певною «інституціоналізацією». На противагу цьому спочатку ми приймаємо, що $є$ певні ознаки наукових норм, як і також наукова діяльність - які завдяки цим нормам генеруються, які $\epsilon$ спільними для різних галузей науки. Звідси що це переважно мають на увазі як поняття «наука», можна легко переконатися на прикладі: хто вважає астрологію наукою, робить це, хоча вона не $\epsilon$ предметом, який викладають в університеті (отже, залежною від інституціоналізації), а хто не вважає астрологію наукою, не змінить одразу свою думку, якби було створено астрологічні кафедри (Stopin, 2015, p. 16).

Давайте надалі виходити 3 повсякденного мовного вживання, тоді з'являються такі критерії науковості: критерій для науковості норми або системи норм $є$ правдою. Хоча часто вважають, що це було б прагненням наукової діяльності до правди, тобто до справжніх норм, які приймають рішення про науковість чи не науковість - проте це $є$ правильним лише з позиції науки як наукової діяльності. Якщо в науковій теорії неправдиві норми помилково видаються правдивими, то це помилка, недосконалість наукового методу. Те, що помилка неминуче належить до людського пізнання, що з цього не може бути довершеного наукового методу, тут нічого не змінити.

Правда (істина) і теорія правди (істини)

Оскільки правда (істина) теорій є загальним критерієм ії науковості, $€$ намагання поняття правди ввести до сфрери Загальної наукової теорії. Оскільки в наступному частіше застосовують досить неохоплене поняття «істинний (справжній)», видається необхідним коротке зауваження до так званих теорій істини.

Так звану теорію кореспонденції правди покладено переважно в основу науки, проте не в загальному. Згідно з нею, істина є відповідністю висловлювання (вираження) із фактами, точніше висловлювання $\epsilon$ тільки тоді істинним, якщо виражений у ньому зміст дійсно існує. Це є та теорія правди, що $€$ підґрунтям щоденного мислення. Іٓї осмислення стало причиною насамперед формулювання «Відповідність із фрактами»: предмет висловлювання належить іншій формі дійсності або щонайменше, якщо предмет висловлювання $є$ висловлюванням іншого мовного рівня, ніж до самого висловлювання. Відколи вчений А. Тарський робив успішні спроби щодо нового обґрунтування теорії кореспонденції у сфері формалізованих мов, цю проблему можна розглядати як розв'язану.

Проте, згідно з теорією консенсусу (згоди) правди (істини), висловлювання $\epsilon$ лише тоді істинним, якщо існує консенсус щодо висловлювання. Нині слід зазначити, що точне формулювання цієї теорії правди надано в різних версіях, оскільки, з одного боку, не існує консенсусу щодо багатьох основоположних норм, хоча в багатьох цих випадках мусить бути правдивою одна з протилежних норм із логічних причин, а 3 іншого боку - можна створити «штучний» консенсус через впливи, які безпосередньо не залежать від наукової діяльності (переконання, перекручування інформації) - у будь-якому випадку на певний час серед окресленого кола осіб. Різні версії теорії консенсусу формулюють постійно деякі гіпотетичні додаткові умови, які поєднані зі здійсненням консенсусу та повинні турбуватися про «непідробний» консенсус. Теорія консенсусу істини має усувати певні фрілософрські проблеми правди. Тому ми підходимо до них доволі ґрунтовно, оскільки пізніше - у зв'язку з критикою юридичної прагматики - мусимо ще раз повернутися до проблеми. Передусім - i це $\epsilon$, мабуть, безпосереднє бажання ії представників видається, що вона робить можливим відтепер напряму говорити про правду норм.

Заперечення, які переважно порушують проти теорії консенсусу істини, призводять до того, що умови, за яких встановлено консенсус (або, точніше, домовлено стосовно теорії дискурсу), або не є можливими до реалізації, або ґрунтуються на фрікціях (вимислах). Оскільки теорія консенсусу відходить від фрункцій, стає очевидним принциповий недолік. Він лежить уже в стосовно нього існує консенсус. Проте тепер з'ясування, чи існує консенсус і в чому він полягає, не є тривіальним (постає питання, як думає науковець певної галузі про певну проблему). У такий спосіб висунуто не лише заперечення, що теорія консенсусу не була б практично зручною для користувача - що вона фрактично $€,-$ але повинно бути показано, що це в жодному випадку не $є$ зайвим, спитати про наявність консенсусу.

Оскільки консенсус $€$ феноменом, що ґрунтується на реальних уявленнях людей, сумнівно не існує консенсусу про те, чи існує консенсус про висловлювання, його необхідно було б спочатку створити, так, що ствердження істини висловлювання передбачає безконечний дискурс.

Лише за умови: якщо теоретик консенсусу оцінював би питання, чи наявний консенсус насправді, згідно 3 теорією кореспонденції! (Що він також тоді робить, якщо вигадує: якщо 
існує консенсус щодо питання, мав би існувати «розважливо» також консенсус щодо наявності консенсусу). І насправді, існує ця підозра. Консенсус про щось ґрунтується на думці людей.

Це змушує вірити, що всі мали б у це вірити, у що він вірить, і водночас кожен мусить вірити в те, у що вірять усі. Консенсус залежний від думки, а вона передбачає консенсус тощо. Це рекомендує полемічну замітку, що теорія консенсусу могла б уже тому бути неправильною, бо не існує консенсусу щодо ії істинності (Tarskiy, 1972, р. 136-145).

Проте існує наступна можливість пояснити теорію консенсусу: згідно з цим тлумаченням, в основі теорії консенсусу насправді лежить теорія кореспонденції, лише теорія консенсусу замість того, щоб посилатися на висловлювання про дійсність, посилається на висловлювання про думки (судження) щодо дійсності. Теорія консенсусу посилається, з огляду на це, на інший предмет і не $є$ в цьому сенсі альтернативою теорії кореспонденції.

Стосовно так званої теорії когерентності (зв'язку) істини достатньо вказівки, що вона спочатку утворює лише кваліфікованим чином відносне поняття істини. Згідно з нею, норма $\mathrm{C} \epsilon$ істинною, якщо вона виступає у когерентній, тобто логічно сумісній, системі норм. Тоді не $є$ істинною кожна в собі логічно суперечлива норма. Те, що не можна одночасно стверджувати дві норми, які виключають одна одну, випливає також із теорії когерентності, проте це випливає вже із Загальної логіки. Якщо ми застосовуємо поняття «істина», тоді ми вважаємо це поняття завжди належним до - якщо також проблематичної - матеріальної істини стосовно сфери предмета, який розглядають, не лише на диференційовану систему норм, що побудовано довільно. Отже, мова йде постійно про відносини між нормою та змістом - про кореспонденцію норми щодо змісту.

Кожна наука користується інструментарієм логіки. Наслідкові відносини між нормами роблять можливими лише щось таке, як обґрунтування та диференціювання. Жодна наука не виходить із протиріччя без якогось формулювання норми та норми 3 ідентичності. Таким чином не стверджується, що «логіка» (що також завжди це було б) була б підгалуззю Загальної наукової теорії. Лише зазначають, що так звані логічні принципи є передумовою кожної науки, як і також науки логіки. Без скритого (наявного) «взяття» за основу логіки не створюється і не застосовується найпростіша формальна система (Astafev, 1968). Те, що ми це не постійно помічаємо, полягає в тому, що вже неформальна повсякденна мова, у якій мають застосовувати терміни та правила формальної системи, є підґрунтям основних правил логіки й етичного пізнання (Berdiaiev, 2015, р. 233-234).

\section{Наукова новизна}

Наукова новизна одержаних результатів полягає у тому, що досліджено та представлено дослідницьку програму правознавства через розуміння ії як науки. 3 наукової теорії можна вибирати, за якими критеріями слід перевіряти наукові положення на їхню правдивість. Можливо, хтось навіть очікує, що наукова теорія вкаже йому шлях («метод»), яким потрібно лише механічно слідувати, щоб досягнути мети наукового пізнання. Які очікування і яку відповідь також бажає підготувати наукова теорія: для науково-теоретичних норм так само, як і для будь-яких інших норм, необхідні критерії перевірки. Вона з'являється як наука, що потребує наукової теорії, для якої надалі ніщо інше не може діяти.

\section{Висновки}

1. XX століття розширило смисловий та інструментальний зміст методології наукового пізнання. Фактично методологія наукового пізнання становить теорію наукового пізнання, що досліджує пізнавальні процеси.

2. Суб'єктом пізнання визнано людину, яка опанувала історично вироблені форми пізнавальної діяльності.

3. Звернено увагу на посилення нетрадиційних засобів і методів пізнання. Висвітлено взаємозв'язок із вимогами наукової методології.

4. Розвиток формальної логіки, який розпочався в останній третині минулого століття, не лише призвів до методичної появи у «формальних науках» логіки та математики, а й спонукав до осмислення всіх наукових сфрер, i таким чином сприяв становленню наукової теорії як окремої галузі науки.

5. Ми стоїмо перед ситуацією, коли дедалі більша потреба в дослідженні протистоїть дослідницьким розробкам (кількість яких збільшується), які залишаються в розробленні через їхню недостатню координацію. Виникає небезпека, що підвищена складність наукових досліджень зменшує ефрективність правознавства та призводить до того, що правова практика в майбутньому відвертається від правознавства та відхиляється від тимчасової теорії.

6. Представлено дослідницьку програму правознавства. 3 науково-історичної точки зору це як консервативне, так i революційне прагнення. Наше прагнення $€$ консервативним, оскільки воно спрямоване не на заміщення наявних виявів уявно оригінальними, а на консолідацію правознавства. На противагу цьому воно виявляється як революційне, оскільки спрямоване на новий шлях правознавства: реалізувати дослідницьку програму означає безперервне (постійне) дослідження, а отже, 
відмову від певних коливань модними течіями між забутим і нововідкритим, означає розуміти правознавство підкреслено як науку.

7. Питання організації науки є питанням про передумови, на які слід зважати, щоб можна було займатися спеціальною науковою діяльністю. Очікування (надія) наукової теорії полягає в тому, що 3 неї можна обирати, за якими критеріями перевіряти наукові норми на їхню правдивість. Цій проблемі фундаменту наукової теорії не приділено належну увагу. Проте якщо ми розмірковуємо про організацію правознавства, то не можемо залишити цю проблему поза увагою, адже це ключова проблема науки.
8. За допомогою трилеми висвітлено поняття «обґрунтування». У науці $€$ необхідним вимагати обґрунтувань і подавати їх, зазначав учений В. Вернадський. Наука ґрунтується на основних передумовах, де постає питання аргументувати.

9. Загальна наукова теорія намагається відповісти на важливий аспект запитання «що $є$ наука?». Ті науково-теоретичні теорії, які нібито діють лише для природничих наук або інших окремих галузей наук, можна було б назвати, на противагу Загальній науковій теорії, «Особливою науковою теорією».

10. Кожна наука користується інструментарієм логіки. Тому логічні принципи $\epsilon$ передумовою кожної науки, як і також науки логіки.

\section{REFERENCES}

Albert, Kh. (2003). Traktat o kriticheskom razume [A treatise on the critical mind]. (I.Z. Shyshkova, Trans). Moscowa: Editorial URSS [in Russian].

Astafev, V.K. (1968). Zakony myshleniia $v$ formalnoy i dialekticheskoy logike [Laws of thinking in formal and dialectical logic]. Lvov [in Russian].

Bekon, F. (1977). Sochineniia $v$ dvukh tomakh [Works in two volumes] (2 ${ }^{\text {nd }}$ ed.). A.L. Subotina (Eds.). Moscow: Mysl [in Russian].

Ben, Ya.V. (2019). Modernizatsiia mekhanizmu realizatsii demokratii uchasti $v$ umovakh reformy mistsevoho samovriaduvannia $v$ Ukraini [Modernization of the mechanism for the implementation of participatory democracy in the context of local government reform in Ukraine]. Ekspert, Expert, 2(4), 8. doi: https://doi.org/10.32689/26179660-2019-4-2-146-158 [in Ukrainian].

Berdiaiev, M. (2015). Problema etychnoho piznannia [The problem of ethical cognition]. Systema suchasnykh metodolohii, System of modern methodologies. (Vols. 1-4). (A.V. Furman, Trans). Ternopil: TNEU [in Ukrainian].

Kaminska, N., Siokh, K., \& Demidenko, V. (2018). Trends in the Development of International Legal Personality and Subjects of International Law: Theoretical Analysis. Opcion, 34(85), 507-520.

Kelman, M.S., \& Kelman, R.M. (2018). Kontseptualizatsiia problemy piznannia naukovykh teorii u zahalnoteoretychnomu pravoznavstvi [Conceptualization of the Problem of Knowledge of Scientific Theories in General Theory of Law]. Priorytetni napriamy doslidzhen rozvytku derzhavy i prava $v$ umovakh yevroatlantychnoi intehratsii Ukrainy, Priority areas for research on state and law development in the context of Ukraine's Euro-Atlantic integration. N. Kaminska (Eds.). Kyiv [in Ukrainian].

Kelzen, H. (2015). Chistoe uchenie o prave [Pure doctrine of law] (2 ${ }^{\text {nd }}$ ed.). (M.V. Antonova, S.V. Lezova, Trans). SPb.: Alef-Press [in Russian].

Popper, K. (2004). Logika nauchnogo issledovaniia [The logic of scientific research]. Moscow. doi: http://doi.org/10.5281/zenodo.51603 [in Russian].

Shopengauer, A. (1992). Sobranie sochinenii v piati tomakh [Collection of works in five volumes]. (Yu.I. Aykhenvald, Trans). Yu.N. Popov, A.L. Chanyshev (Eds.). Moscow: Mosk. Klub [in Russian].

Stopin, V. (2015). Nauka [Science]. Psykholohiia i suspilstvo, Psychology and society, 2, $16-25$ [in Ukrainian].

Tarskiy, A. (1972). Istina i dokazatelstvo [Truth and proof]. Voprosy filosofii, Philosophy Issues, 8, $136-145$ [in Russian].

Zahorodnii, A. (2018). Idei Volodymyra Vernadskoho i suchasnist [Vladimir Vernadsky's ideas and modernity]. Svit, World, 9-10 [in Ukrainian].

Volosheniuk, O.V. (2019). Perevahy i nedoliky polityky multykulturalizmu [Advantages and disadvantages of multiculturalism policy]. Forum Prava, Forum of Law, 56(3), 6-12. doi: http://doi.org/10.5281/zenodo.3240906 [in Ukrainian].

\section{СПИСОК ВИКОРИСТАНИХ ДЖЕРЕЛ}

Альберт Х. Трактат о критическом разуме / пер с нем., вступ. ст. и примеч. И. З. Шишкова. М. : Едиториал УРСС, 2003. 264 c.

Астафьев В. К. Законы мышления в формальной и диалектической логике. Львов, 1968. 208 с.

Бэкон Ф. Сочинения : в 2 т. 2-е изд., доп. / под общ. ред. А. Л. Суботина. М. : Мысль, 1977. Т. 1.

Бень Я. В. Модернізація механізму реалізації демократії участі в умовах реформи місцевого самоврядування в Україні. Експерт. 2019. № 2 (4). С. 8. doi: https://doi.org/10.32689/2617-9660-2019-4-2-146-158.

Бердяєв М. Проблема етичного пізнання. Система сучасних методологій : хрестоматія : у 4 т. / упоряд., відп. ред., пер. А. В. Фурман. Тернопіль : ТНЕУ, 2015. Т. 1. С. 233-244.

Kaminska N., Siokh K., Demidenko V. Trends in the Development of International Legal Personality and Subjects of International Law: Theoretical Analysis. Opcion. 2018. T. 34. No. 85. P. 507-520. 
Кельман М. С., Кельман Р. М. Концептуалізація проблеми пізнання наукових теорій у загальнотеоретичному правознавстві. Пріоритетні напрями досліджень розвитку держави і права в умовах євроатлантичної інтеграції України : монографія / за заг. ред. Н. Камінської. Київ, 2018. С. 63-83.

Кельзен Г. Чистое учение о праве. 2-е изд. / пер. с нем. М. В. Антонова, С. В. Лезова. СПб. : Алеф-Пресс, 2015. 542 с. Поппер К. Логика научного исследования. М., 2004. 330 c. doi: http://doi.org/10.5281/zenodo.51603.

Шопенгауэр А. Собрание сочинений в пяти томах / пер. Ю. И. Айхенвальда; под ред. Ю. Н. Попова; примеч. А. Л. Чанышева. М. : Моск. клуб, 1992. 340 с.

Стьопін В. Наука. Психологія і суспільство. 2015. № 2. С. 16-25.

Тарский А. Истина и доказательство. Вопросы фрилософрии. 1972. № 8. С. 136-145.

Загородній А. Ідеї Володимира Вернадського і сучасність. Світ. № 9-10.

Волошенюк О. В. Переваги і недоліки політики мультикультуралізму. Форум права. 2019 . № 56 (3). С. 6-12. doi: http://doi.org/10.5281/zenodo.3240906.

Стаття надійшла до редколегії 13.02.2019

Kelman M. - Doctor of Law, Professor, Professor of the Department of Theory and Philosophy of Law of the National Scientific Research Institute of the Lviv Polytechnic National University, Lviv, Ukraine

ORCID: https://orcid.org/0000-0002-4393-4626;

Kelman L. - Ph.D in Law, Associate Professor, Associate Professor of the Department of Civil Law and Process of the Lviv State University of Internal Affairs, Lviv, Ukraine

ORCID: https://orcid.org/0000-0001-6884-0389;

Romanska I. - Postgraduate Student of the Lviv State University of Internal Affairs, Lviv, Ukraine ORCID: https://orcid.org/0000-0001-6970-184X

\section{Understanding the Methodology of Cognition of Scientific Theories in Jurisprudence}

The purpose of the article is to present a research program of jurisprudence. From a scientific and historical point of view, this is a conservative aspiration, since it is aimed not at replacing existing manifestations with the seemingly original, but at consolidating jurisprudence, as well as being revolutionary, since it aims at a new path of jurisprudence: to carry out a research program means continuous (continuous) research, and therefore abandoning certain fluctuations in fashion trends between the forgotten and the newly discovered means to understand jurisprudence emphasized as a science, and therefore a turn away from a politicized "decision-making meeting». The methodological basis of the study is a number of conceptual approaches, general scientific and specially scientific methods. Topical issues of methodology of cognition of scientific theories are considered. The scientific theories of modern jurisprudence, their structure are investigated. The development of jurisprudence theories in the general structure of scientific theories is substantiated. It is noted that the question of scientific theory has had a marginal impact on jurisprudence, in any case to this day. If it is so that the value of scientific and theoretical research is increasingly relevant to law, then it cannot be argued that the scientific theory of law is still not in sight in a particular form. Describing its current state, it is necessary to state the field of tension, on one side of which stands a cognitive effort around the scientific-theoretical basis of science, and on the other - the so-called legal dogma, which is served (if at all served) by the existing temporary theory about its basis. Attention is drawn to the organization of jurisprudence as a science. The problem of cost freedom of science, which will be of great interest to us and will concern us, is considered. It is argued that every science uses the tools of logic. It is necessary to distinguish between statements about valuation and valuation: statement about valuation is the statement that certain valuations are interdependent in the system of value, or also whether someone has comprehended certain valuations. Instead, conducting an evaluation means taking the evaluation, evaluating yourself. The "freedom of science» value proposition does not imply that statements about appraisal do not belong to science, which would be unscientific to make appraisal a subject of knowledge. The postulate of the value freedom of science only implies that the evaluation (direct evaluation) does not belong to scientific activity. Scientific novelty. So general scientific theory seeks to answer an important aspect of the question "what is science?» The question of the organization of science is a question of the prerequisites that must be derived in order to be able to engage in specific scientific activities. The expectation (hope) of a scientific theory is that it is possible to choose by what criteria it is possible to test scientific norms for their truth. One might even expect that scientific theory may indicate to it a path ("method") that only needs to be followed mechanically to reach the goal of scientific knowledge. What expectations do they have, in particular, and what answer does the scientific theory want to prepare: for scientific and theoretical norms, as for any other norms, criteria for validation are required. Scientific theory emerges as a science which, in turn, requires a scientific theory - for which nothing else can work. Conclusions. It is justified that in this way the scale (sequence, gradation) has arisen, the meta-meta is the aim of scientific theory, which is infinite and therefore cannot be fully traced, and thus our test criteria may not be substantiated. Those scientific-theoretical theories that are supposedly valid only for the natural sciences or other specific fields could be called, in contrast to the General Scientific Theory, a «Special Scientific Theory».

Keywords: theory; science; methodology; method; system; structure; organization; truth; logic; program; jurisprudence. 